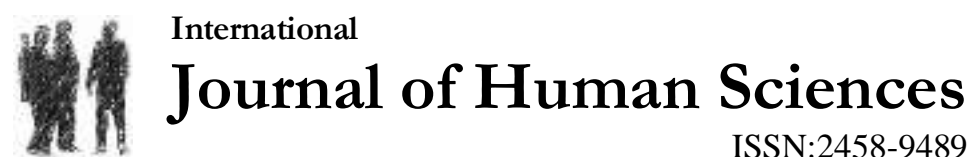

Volume 14 Issue 3 Year: 2017

\section{Analysing the communicative aspect of Turkish minstrelsy tradition and story-telling performance in the frame of multiple intelligences theory ${ }^{1}$}

\author{
Özlem Demren ${ }^{2}$
}

\begin{abstract}
Oral narratives have an effective educational power in their context and they are among the most important conveyors of collective cultural memory as an eficient communicative tool. Perform an important function and occupy an important place in Turkish society, folk stories and their performative context too have an educational and communicational aspects.In the established communication between the minstrel (âș1k/folk story performer/story-teller) and his audience, it is created a cultivation ground for the people who share the environment; perception and intelligenceareasof performer and his audience are used effectively. The people who share the performative process of folk story learn to use the areas of multiple intelligence variously and make them efficiently active; and in a sense, they learn to improve the way of thinking in which is spesific to their culture. The important thing is here which intelligence areas are used and being prominence in this process.In the frame of our paper, to understand these process we use the Multiple Intelligences Theory which is improved by Howard Gardnerin 1983, as a psychological theory, and it has been used worldwide effectively in the educational area. In this sense, Multiple Intelligences Theory gives us a different perspective to evaluate and understand the educational and communicational aspects of narrative context.In this paper, it will be an interpretation about the performative context of Turkish minstrelsy tradition in an interdisciplinary frame.
\end{abstract}

Keywords: Turkish story-telling; minstrelsy; performance; multiple intelligences theory

\section{Introduction}

In an interdisciplinary frame between folklore and psychology ${ }^{3}$, in this study it is analysed the communicative aspect of Turkish minstrelsy tradition and story-telling performance in the frame of Multiple Intelligenges Theory. In this context, firstly it will be given some information regarding Turkish story-telling tradition in its context.

Traditional folk narratives are the sources informing of the culture in which they are born (Porteli 2005:223). Turkish folk stories as a type of traditional narrative are "the earliest works of the period between nomadic life and settled life, and they are narratives about such topics as love, heroism, etc whose source is Turkish, Arabic-Islamic and Indo-Iranian; which are narrated by âşık

\footnotetext{
1 This study presented at the symposium of "SSHIF-2015/Social Sciences and Humanities in Focus" held in Poland is based on the Ph.D. thesis entitled "Interpreting the Traditional Folk Narratives in the Frame of The Multiple Intelligences Theory", (2009/Hacettepe University).

2 Assist. Prof., Cumhuriyet University, Faculty of Literature, Department of Turkish Folklore, odemren@,cumhuriyet.edu.tr

${ }^{3}$ See another interdisciplinary study between folklore and psychology (Demren 2009).
} 
Demren, Ö. (2017). Analysing the communicative aspect of Turkish minstrelsy tradition and story-telling performance in the frame of multiple intelligences theory. Journal of Human Sciences, 14(3), 2259-2267. doi:10.14687/jhs.v14i3.4564

(minstrel) and meddah and which are a mixture of prose and poetry". Folk stories contain motifs and episodes, they are rich in form and content, and they are significantly reflective of Turkish folk culture (Alptekin 1997:7). Turkish folk stories have tradition based on oral narration. Considering Turkish folk stories according to performance theory, which is a context-based theory ${ }^{4}$, there are five elements of them: 1. Story-telling tradition; 2. Narrator -minstrel; 3. The audience -circle of listeners; 4. Turkish folk stories -as oral texts, 5. Music -accompanied by Bağlama (Görkem 1998:108).

The origins of Turkish tradition of story-telling dates back to ozan/poet-singer tradition in Central Asian period. The tradition of Turkish folk story-telling performance kept its existence of specific form from past to present. Folk stories are performed (or rather narrated) by "story-tellers called minstrels who have the abilities such as immitating others, singing accompanied by the musical instrument called bağlama, speaking in front of an audience and influencing people beside having good imagination. Turkish folk stories as oral texts usually include verse parts and are called stories with folk songs, they are accompanied by the instrument Bağlama (Görkem 1998:108-111). Learning the verse parts and use them effectively in front of the audience are depens on knowing the melody patterns and using them succesfully within the melody-word relation (Özarslan 2002:401). Minstrels who are raised in master-apprentice relationship can themselves compile stories and they can also be "conveyer" of stories in the narrative tradition. Those minstrels and their audience are the members of the same society, and this situation ensures the mental harmony of the performer and whose listeners. In this sense, the story-teller and the listeners are in mutual communication in the context of Turkish folk story, and therefore, they are mutually influenced by their reactions ${ }^{5}$ (Görkem 1998:108-111).

\section{Multiple intelligences theory and performative frame}

Multiple Intelligences Theory is a theory of psychology suggested by Howard Gardner in 1983, and it distinguishes eight areas of intelligence (Gardner 1996). The thought that our different abilities are associated with different areas of intelligence attaches value to any type of human ability, and Gardner, in connection with this thought, calls all of the fields as the areas of "intelligence" or "ability". The areas of multiple intelligences are as in the following: 1. Linguistic Intelligence: It Involves such basic skills as active listening, reading, speaking and writing. Emphasis is laid on ingenuity in syntax, on ability to persuade others, on memory power and on skills to use the language effectively; 2. Musical Intelligence: Individuals having this type of intelligence have such developed abilities as sensitivity to rhythm, and recognition of changes in timbre and tone; 3 . Logical-Mathematical Intelligence: Abilities such as recognising concepts, working with abstract symbols, setting up cause-effect relations between the fragments of knowledge, and seeing the associations between those fragments are remarkable in this type of intelligence; 4. Spatial Intelligence: Ability to design three dimensional objects, have spatial comprehension in the mind and thus to do various operations with them is remarkable in this type of intelligence; 5 . BodilyKinesthetic Intelligence: Ability to express one's feelings and thoughts by using the whole body or parts of the body, solve problems and produce an outcome is remarkable; 6. Interpersonal Intelligence: This area of intelligence is related with individuals' communication with their environment and with their capacity to understand others correctly; 7. Intrapersonal Intelligence: Individuals' ability to recognise and understand themselves and their ability to recognise their own feelings, the degree of their emotional responses and the process of thinking are available here; 8 . Naturalist Intelligence: Individuals having this type of intelligence have developed ability to classify

\footnotetext{
${ }^{4}$ For more information about Performance Theory, see (Çobanoğlu 2002:265-316; Ekici 2007:128-131).

${ }^{5}$ For more information about how minstrels create the communicative process mutually with their audiences during narration, see (Çobanoğlu 2000; Başgöz 2012). For an interview about the word and narration studies in Turkish minstrelsy tradition, see (Pultar and Aygün Cengiz 2003:187-203).
} 
Demren, Ö. (2017). Analysing the communicative aspect of Turkish minstrelsy tradition and story-telling performance in the frame of multiple intelligences theory. Journal of Human Sciences, 14(3), 2259-2267. doi:10.14687/jhs.v14i3.4564

and make distinctions and high levels of sensitivity to the environment (Gardner 1993; Gardner 1999; Gardner 2004a; Gardner 2004b; Gardner, Konhaber and Wake 1996; Yavuz 2001; Demirel, Başbay and Erdem 2006).

According to Gardner (1996:211), every normal human has all of these areas of intelligence or ability, but individuals differ in terms of certain profiles of intelligence which come into prominence. Those prominent profiles represent the combinations of relative weaknesses and strengths of individuals' intelligence that they employ in solving problems or in creating a product of value in a culture. According to Gardner (1996:243), areas of intelligence and their development are also related with the cultural context in which individuals live. The development of various abilities is determined according to the needs dominating in different cultures. In this sense, Gardner's theory makes us attach importance to each area of intelligence or ability which a culture values or which adds value to a culture. Gardner (2004b) points out that each culture is a part of abilities available and used in the traditional life of each culture, of human nature and of intelligence. When seen from this perspective, performance of traditional folk narration requires that certain areas of intelligence be developed and that the audience develop their own areas of intelligence or that they perceive the way in which their interests develop.

A symbolic language functioning in oral cultural context is used in traditional folk narration. With its symbolic language, oral environment of culture is influential in the development of the performers' abilities, of the message conveyed and of the abilities of those receiving the message. The symbolic content of folk narratives creates an environment where verbal-linguistic intelligence becomes functional in the oral cultural context to give the traditional and cultural values. Each type of narration is a "speech" in the context of performance theory. In Dell Hymes' (1971:64-65) words, each "speech" creates its own "speech community". A speech community is composed of "those who share the speech and the basic forms of rules to speak". In this sense, every form of speech is conveyed in an "interpretive framework" as a message in terms of communication with the audience. The interpretive framework is perceived figuratively. The "framework of real meaning", on the other hand, is the framework in which words are perceived in their lexical meaning. In this sense, performance is regarded as a framework and this framework has two aspects: the "real" and the "interpretive" aspects". These frameworks are important in terms of communication between the performer and the audience. The performer adds meanings to his "speech" by using his tone of voice or the form, requires that what he tells be interpreted and understood by the audience through these meanings (serious, joke, etc). That the performance is regarded as a framework means that it is "a way of using language or a way of speaking", and "it lays the listener responsibilities based on knowledge and on the ability to use the language socially in terms of communicative competence" in the context of performance (Çobanoğlu 2002:273-274). On considering this situation in the framework of Multiple Intelligences Theory, performance "as a use of language and a way of speaking" receives its power as a framework primarily from the active use of verbal-linguistic intelligence. Here, active use means loading responsibility to both the performer (being active in oral conveying) and the audience expected to perceive the performance (being active in listening). In other words, this means being two directional for the communication, and this dynamism in the context of oral culture can be interpreted as spatialising the traditional content in a special context.

The concept expressing the start and termination of a performance as a framework is "performance framework key". This concept " expresses the information on the one who gives the message, how to interpret the message and how to solve it by putting it in a framework". Performance framework keys have culture-specific properties, which stem from frameworks depending on the "speech community" (Çobanoğlu 2002:276). Performance framework keys are the elements exhibiting the "logic of traditional oral folk narrative". On interpreting this according to Multiple Intelligences Theory, it becomes clear that linguistic intelligence which starts and sustains communication in the context of oral culture is used in combination with logical- 
Demren, Ö. (2017). Analysing the communicative aspect of Turkish minstrelsy tradition and story-telling performance in the frame of multiple intelligences theory. Journal of Human Sciences, 14(3), 2259-2267. doi:10.14687/jhs.v14i3.4564

mathematical intelligence because the narrative to be conveyed in the active use of words is expected to have a logical framework. The establishment of the context of each narration manifests itself in the performance framework keys representing the logical establishment of traditional folk narrative. This process is important in determining the type of narration to be created. logicalmathematical Intelligence involves the ability to set up the causal relations and to develop logical strategies for this. The active use of performance framework keys in this sense is related with the active use of logical-mathematical intelligence in the context of oral culture to establish the types of traditional folk narratives. The type of narration is formed and performed through linguistic intelligence, logical-mathematical intelligence and the other types of intelligence in combination in the process of communication between the performer and the audience in the context of performance.

\section{Turkish folk story performance and multiple intelligences theory}

Oral narratives have properties specific to skills of those who create them and differing functions and fiction (Porteli 2005). For this reason, oral narratives need different and specific interpretive vehicles. From the perspective of this study, it may be said that the way folk stories are interpreted is shaped by the abilities of performers but that the ability is supported by the patterns of story-telling and the expectations of the audience are taken into consideration for the purposes of admiration on the part of the audience. The performer influences the audience via his narration and the audience influences the performer via their expectations; and thus mutual interaction is established with the help of oral narration. In this sense, word creates and sustains the environment for communication in oral cultural context. How and for what purposes traditional folk narratives having their own specific symbolic structure use the symbolic language is important in the context of oral culture where the ability to report orally -which is an ability of linguistic intelligence- is displayed. With its symbolic language, the environment of oral culture has guiding influences in the abilities of performers and of the receivers of messages and in their education. The performance is shaped according to the message conveyed from the perspective of the performer and the audience.

From the perspective of Performance Theory, firstly the "performer" is remarkable. Which areas of intelligence are used by the performer as the creator and the conveyor of the message is important for our study. It is used other areas of intelligence in combination with linguistic intelligence so that folk stories are put into words and the communicative process is started and sustained through linguistic intelligence. The performer's priority is to be able to perform the text of the story orally in front of the audience with no hesitation in speaking. A minstrel should be selfconfident in narration, who acquires this skill during his long period of apprenticeship training by listening to and watching other performers. A pattern of composition on how to construct the performance is shaped in the minds of minstrel during the long period of apprenticeship. The specific logic of story-telling tradition assures that we understand in what framework the minstrel puts his story and how he does it; how he progresses throughout his story without getting lost and how he determines what order to pursue during his performance. Issues such as how to make an appropriate beginning to the story, how to form appropriate linking points for moving over between the consecutive parts of the story, how to organize the important scenes of the story and how to conclude the story are shaped in the mind of a minstrel through the time. Such patterns form the rationale of creating a folk story, and they help us to understand how the logical framework of a story-telling is shaped in the mind of a minstrel.

When evaluated within the framework of Multiple Intelligences Theory, we notice the effects of logical-mathematical intelligence on minstrel's logical understanding and patterning which enables him to think in a certain logical framework, to set up meaningful cause-effect relationships between pieces of information and thus to develop a plan of narration accordingly. For the performer who creates an appropriate logical schema to perform a story is subjected to use logical- 
Demren, Ö. (2017). Analysing the communicative aspect of Turkish minstrelsy tradition and story-telling performance in the frame of multiple intelligences theory. Journal of Human Sciences, 14(3), 2259-2267. doi:10.14687/jhs.v14i3.4564

mathematical intelligence and spatial intelligence actively and in combination. It is inevitable for a minstrel who has not understood the structural composition logic of folk story sufficiently to have difficult times in front of the audience during his performance. A minstrel has full knowledge of the folk story that he is going to perform, and the logical framework of composition influenced by logical-mathematical intelligence helps the minstrel both to compose a logical narrative with this knowledge and to find his way during his performance, and it also helps to lengthen or shorten his story during his improvisation. In this sense, the logic of the composition which has specific content is influenced by the extent to which the minstrel uses logical-mathematical intelligence actively. A performer who can use this area of intelligence actively can easily comprehend the composition logic of the folk story performances he listened to/watched during his long period of apprenticeship, and he himself can also put his narration appropriately into the logical framework of composition which he comprehended well. In this way, he can perform his story in its wholeness of composition and can please his audience.

The way a folk story performer's of using logical-mathematical intelligence is certainly influenced by the oral tradition of the society into which he is born. The plan followed during the creation process of a narration should suit to the expectations of the audience (Yildirim 2002:6066). In this sense, the performer has to develop a logical framework of the narration fitting the expectations of his audience. Here, the logical-mathematical intelligence of the audience should be stimulated by the performer in an appropriate way. The audience's logical expectations of the narration and their comprehension of the cause-effect relationships reflect an expectation of a story plan. Only performers who can meet the logical expectations of the audience which are shaped as a result of the traditional oral culture surrounding the audience are considered to be successful by the society.

"In every instance of story-telling" as a case of communication, "the sender and the receiver of the message communicate each other in an encoded message form (traditionaly shaped meanings, responses and equivalences which are agreed on) (Çobanoğlu 2002:311-313). These agreed on, traditionally shaped "meanings, responses and equivalences" form the context of performance, they influence and are influenced by the performer's and the audience's ways of using logical-mathematical intelligence - that is to say, their logical framework during thinking.

According to Performance Theory, a minstrel is the personal dimension and he reflects the collective memory into his performance by blending it with his personal interpretations to the extent that his ability permits. The minstrel's ability to fulfill his performance depends on his ability to understand the traces left by collective memory on his internal feelings. From the perspective of the theory of multiple intelligences, it is important for the performer to be able to use intrapersonal intelligence actively. In this area of intelligence, individuals' ability to recognise and understand themselves and their emotional responses and their intellectual processes is prominent. The performer, who finds the marks of the society in his internal feelings and who keeps the pulse of the society with the help of collective memory, should accurately identify the feelings, awareness, demands, motivation and biases of the society in addition to his own feelings influenced by the society; and this is directly proportional to the developedness of interpersonal intelligence. Well developed interpersonal intelligence on the part of the performer is also important in that the performer using this type of intelligence actively is capable of leading the listeners/viewers of the performance. Interpersonal intelligence is associated with individuals' capacity to understand and communicate with others appropriately that being able to feel differences of temperament, character and bias between individuals forms the basis of this type of intelligence. A minstrel dominantly having this type of intelligence can correctly sense the response that the audience is probable to give to the narration due to his sensitivity to their temperament and character, can respond correctly to the audience, and thus can construct the narration suitable and pleasing to the audience. 
Demren, Ö. (2017). Analysing the communicative aspect of Turkish minstrelsy tradition and story-telling performance in the frame of multiple intelligences theory. Journal of Human Sciences, 14(3), 2259-2267. doi:10.14687/jhs.v14i3.4564

A minstrel who has well developed interpersonal intelligence will feel comfortable during his performance and communication with his audience to the extent that he can sense the responses and feelings of his audience. Easy manners in front of the audience will also be manifested in the minstrel's body language during his performance; and here the active use of bodily-kinesthetic intelligence is important. This will affect fluency in the minstrel's narration, which will increase the satisfaction of the audience, and in this way the minstrel will convey the oral text to the others in an appropriate way in the context of narration. In this process, minstrel can feel the expectations of the audience correctly and enrich his narration through improvisation and lengthen or shorten it, when it is necessary.

The audience has the potential to lead the story-teller during the performance through noise and gestures. The performer's meeting the audience's expectations correctly in the narrative context is important in terms of satisfying the audience. In the same way, the responses of the audience to lead the minstrel in accordance with their demands carry the traces of demands and motivation represented by their feelings (here intrapersonal intelligence comes into prominence). The audience aiming to convey the expectations correctly to the performer, to lead what they listen (here linguistic intelligence comes into prominence) to in accordance with their desire and to get satisfaction from the narration has the power to lead the performer with their bodily movement, gestures and mimicry (here bodily-kinesthetic intelligence comes into prominence) and sometimes with words. An entertaining, didactic social context in which efficient and satisfactory interaction is available here is formed between the performer and the audience by means of the oral text to the extent that the audience understands the performer's messages correctly and responds accordingly (here interpersonal intelligence comes into prominence).

The performer who focuses on a narration to sent into the social dimension by using intrapersonal intelligence reaches the audience through interpersonal intelligence and he reaches them orally by using linguistic intelligence. The performer not only understands and reflects his internal feelings but he also conveys the internal feelings of the society leaving marks on his own feelings by using linguistic intelligence. That is to say, the performer who understands himself (by using intrapersonal intelligence) and his audience (by using interpersonal intelligence) starts and sustains the interaction and communication by using his ability to convey. In this sense, words start the communication with the social dimension in the oral cultural context, and minstrels who use words actively start and sustain social interaction through words.

Performer should make what he wants to express suitable to oral conveyance. The performer begins to think in accordance with the patterns of oral conveying for the purposes of social communication. Minstrel's mind gets prepared to do oral conveyance by using the patterns of thinking process suitable for it. Here, the ability to do oral conveyance which falls within the domain of linguistic intelligence comes into prominence and it must be stressed here that how important oral narration ability is in creating and sustaining the context of performance. How skilfully the narration is adapted into the patterns of oral narration and the quality of the oral text depend on the performer's ability to create and convey the words (on how well his linguistic intelligence is developed) and on how he can use this area of intelligence to enrich and diversify his narration; because a minstrel gains prestige according to his ability.

It is very important to go through a certain amount of training to become skilled at storytelling. A person who wants to be a minstrel first listens to masters, watches them and copies them, he extends his repertoire through time, he gains insight into the patterns that masters use (here logical-mathematical intelligence comes into prominence), later he begins to narrate his original texts within the framework of those patterns. Here it should be pointed out that an apprentice with developed linguistic intelligence can comprehend a master narrator better because one of the basic skills of linguistic intelligence is "listening". In this domain of intelligence, the importance of comprehending what is listened to and the capacity of memory are emphasised. It should also be stated that the extent to which musical intelligence is developed is important for both a story-teller 
Demren, Ö. (2017). Analysing the communicative aspect of Turkish minstrelsy tradition and story-telling performance in the frame of multiple intelligences theory. Journal of Human Sciences, 14(3), 2259-2267. doi:10.14687/jhs.v14i3.4564

and an apprentice listening to, watching a master and trying to learn the oral text of a story. An apprentice should also catch up with the rhythm while trying to comprehend the story. The reason for this is that a story is sometimes performed in company with a musical instrument and in a certain rhythm. Melody as a hearing-based object (Porteli 2005) which accompanies folk stories by adding rhythm is also learnt orally in the teaching-learning process requiring a master-apprentice relationship (Prouty 2006). For an apprentice who is a good listener depending on the extent to which linguistic intelligence is developed, who comprehends what he listens to and who thinks of conveying them; the ability to catch up with the rhythm while listening and conveying is importantwhich is also influenced by the extent to which another domain of intelligence, musical intelligence, is used skillfully. The reason for this is that a performer at the stage of apprenticeship can recognise the changes in rhythm, resonance and tone depending on his ability to use musical intelligence and can easily comprehend the rhythmical process of the text depending on his sensitivity to the sound. It might be said that the capacity to combine linguistic intelligence with musical intelligence increases a performer's power to play with oral texts and sounds and to improvise.

An apprentice making trials in front of the audience and trying to improve his ability takes the opportunity to test his aptness for story-telling performance. He tests himself in effective oral narration and selection of rhythms accordingly which are based on linguistic intelligence and musical intelligence, in using the mimicry and gestures to convey appropriate messages reflecting the use of bodily-kinesthetic intelligence because appropriate, right and harmonious use of words, rhythm and bodily movements is important during the performance. Besides, the apprentice checks whether or not the audience can follow him and thus checks the extent to which interpersonal intelligence is sufficient. In order to understand the marks left by the audience and their social expectations on his own feelings, the ability to use intrapersonal intelligence comes into prominence. Besides, for the apprentice to be able to create visual and vivid images is possible through active use of spatial intelligence.

Folk stories are appropriate for improvisation, and they become permanent to the extent that they can satisfy the audience. A minstrel should be able to keep the interest of the audience alive with his narration overlapping with their demands that he should stimulate the spatial intelligence of the audience so that he can create vivid images in the minds of the audience through pictures and shapes and can trigger their imagination and can include the audience in the world of his narrative. Of course, the performer can create images in his own mind to the extent that the power of his spatial intelligence, thus he can enrich the images, and can convey them to the audience effectively to the extent that his linguistic, musical and bodily-kinesthetic intelligences are developed. He can trigger the spatial intelligence of his audience and thus makes sure that images are created in their minds.

During this portrayal, the performer can support the animation of spatial intelligence with the activity of bodily-kinesthetic intelligence. The performer's body language- that is to say, his gestures and mimicry, his bodily movements while he is interpreting the oral text- is determinant in the success of the communication with the audience. Here, thoughts and feelings are expressed by using the whole or parts of the body. Because a performer who can use his bodily-kinesthetic intelligence actively will appeal to the visuality of his audience, the world of emotions created by the context of performance will spark the images. According to Gardner (2004b:171), a visually attractive performance according to traditional acceptance can be considered valuable in its context. When seen from this perspective, an apprentice progressing on the way to become a minstrel learns to display performance complying with traditional acceptance while he is listening to/watching masters. Fulfilling the performance according to traditional acceptance is important for the success of listening/watching.

Compliance between the performer and the audience is important for the context of oral performance to attain satisfaction. It should be stated that some domains of multiple intelligences become dominant in the context of performance in the communication between the performer and 
Demren, Ö. (2017). Analysing the communicative aspect of Turkish minstrelsy tradition and story-telling performance in the frame of multiple intelligences theory. Journal of Human Sciences, 14(3), 2259-2267. doi:10.14687/jhs.v14i3.4564

the audience occuring via oral text, as is shown above. Indeed, which domain of multiple intelligences is dominantly used and in what combinations the domains are used during the performance are influential in terms of which domain of multiple intelligences of the audience -who are accustomed to the tradition- will be activated. The performances that the audience has watched in the process of getting used to the world of narration determine which types of intelligence they are to use dominantly and in what combinations to use them. Being accustomed to the tradition of folk stories stems from this fact.

\section{Conclusion}

The instrument starting the communication between the performer and the audience in the context of oral culture and sustaining it is "the words". In activating the oral communication, thus creating the oral context and sustaining it, in conveying the words effectively to others, and in listening to and comprehending what is said correctly by parties in question, all domains of multiple intelligences are used in differing combinations and with subjective interpretations by individuals, but linguistic intelligence comes into prominence and makes us feel its effect. In other words, linguistic intelligence is dominantly used and it causes the other domains of multiple intelligences (logical-mathematical, musical, spatial, bodily-kinesthetic, interpersonal, intrapersonal and naturalist intelligences) to be used in combinations. In this way, a context of performance turns into an environment of communication having several aspects. The types of intelligence used by the minstrel in the context of performance for his narration enable the stimulation of similar types of intelligence on the part of the audience and thus lead to mental development and a "learning context" in this environment of interaction and communication. The analysisof traditional context of oral narration performance is innovative in terms of comprehending the logic of oral narrative structure, and it helps us to gain a previously unnoticed perspective that it demonstrates the aspects of the richness of folk stories which stimulates different domains and of multiple intelligences and which enables the development of those domains spesific to the culture.

\section{References}

Alptekin, A. B. (1997). Halk hikâyelerinin motif yapısı. Ankara:Akçağ.

Başgöz, İ. (2012). Türkülü aşk hikayeleri - Bir gösterim olarak. İstanbul: Pan.

Çobanoğlu, Ö. (2000).Âşık tarzı kültür geleneği ve destan türü. Ankara: Akçağ.

Çobanoğlu, Ö. (2002). Halkbilimi kuramları ve araştırma yöntemleri tarihine giriş. Ankara: Akçağ.

Demirel, Ö., Başbay, A. \& Erdem, E. (2006). Eğitimde çoklu zeka, kuram ve uygulama. Ankara: Pegem.

Demren, Ö. (2009). Geleneksel halk anlatılarının çoklu zeka kuramı çerçevesinde tahlili. Yayımlanmamış Doktora Tezi, Hacettepe Üniversitesi.

Demren, Ö. (2009). Performans olarak masal icra bağlamı ve eğitsel bir kaynak olarak çoklu zeka kuramı çerçevesinde tahlili. Uluslararası karşılaştırmalı edebiyat ve dil öğretimi kongresi (29 Nisan-1 Mayıs 2009) bildiri kitabı içinde (s.211-218), Ankara.

Ekici, M. (2007). Halk bilgisi (folklor) derleme ve inceleme yöntemleri. Ankara: Geleneksel.

Gardner, H. (1993). Multiple intelligence, the theory in practice. New York: Basic Books.

Gardner, H. \& Others (1996). Intelligence: Multiple perspectives. New York: Harcourt Brace College Publishers.

Gardner, H. (1999). Intelligence refraimed, multiple intelligences for the $21^{\text {st }}$ century. New York: Basic Books.

Gardner, H. (2004a). Zihniyetleri değiştirmek, kendimizin ve başkalarının zihniyetini değiştirmenin sanatı ve bilimi. (Çev. Ahmet Kardam), İstanbul: Türkiye Metal Sanayicileri Yayını.

Gardner, H. (2004b). Zihin çerçeveleri, çoklu zeka kuramı. (Çev. Ebru Kılıç), İstanbul: Alfa.

Gardner, H., Kornhaber, M. L. \& Wake, W. K. (1996). Intelligence: Multiple perspectives. New York: Harcourt Brace College. 
Demren, Ö. (2017). Analysing the communicative aspect of Turkish minstrelsy tradition and story-telling performance in the frame of multiple intelligences theory. Journal of Human Sciences, 14(3), 2259-2267. doi:10.14687/jhs.v14i3.4564

Görkem, İ. (1998). Türk halk hikâyelerinin canlı gösterim (=performance oriented) olarak incelenmesi. Milli Folklor, 37:107-113.

Hymes, D. (1971). Sociolinguistics and ethnography of speaking. (Ed. Edwin Ardener), in social anthropology and language (p.47-93). London: Tavistock.

Özarslan, M. (2002). Âşıklı geleneği içinde âşık müziği ve kimi problemler. Erdem/Türk Halk Kültürü Özel Sayıs1-II, 38:399-409, Ankara: Can Ofset, Erişim: 18.02.2017, http://turkoloji.cu.edu.tr/HALK\%20EDEBIYATI/metin_ozarslan_asiklik_gelenegi_muzi k_problemler.pdf

Porteli, A. (2005). Sözlü tarihi farklı yapan şey. (Çev. Kürşat Korkmaz), Milli Folklor, 68:222-231.

Prouty, K. E. (2006). Orality, literacy and mediating musical experience: Rethinking oral tradition in the learning of jazz improvisation. Popular Music and Society, 29(3):317-334.

Pultar, G. \& Aygün Cengiz, S. (2003). Kardeşliğe bin selam - İlhan Başgöz ile söyleşi. İstanbul: Tetragon.

Yavuz, K. E. (2001). Eğitim-öğretimde çoklu zeka teorisi ve uygulamaları. Ankara: Ceceli Okulları Yayın.

Yıldırım, D. (2002). Türk kahramanlık destanları. (Ed. Saim Sakaoğlu \& Ali Duymaz), İslamiyet öncesi Türk destanları içinde (s.58-67), İstanbul: Ötüken. 